Türk Coğrafya Dergisi
Turkish Geographical Review
Www.tcd.org.tr

\title{
6360 sayılı büyükşehir yasasının Türkiye'nin kırsal yerleşim düzenine mevcut ve muhtemel etkileri: Konya örneği ${ }^{1}$
}

\author{
Current and prospective effects of metropolitan law (no. 6360) on Turkey's rural settlements \\ layout: case of Konya
}

\author{
Bayram Tuncer*a (D) Muzaffer Bakırcı*b \\ a Istanbul Üniversitesi, Sosyal Bilimler Enstitüsü, Coğrafya Anabilim Dalı, Istanbul. \\ 'istanbul Üniversitesi, Edebiyat Fakültesi, Coğrafya Bölümü, istanbul. \\ ORCID: B.T. 000000033825 3735; M.B. 0000-0002-4848-3086
}

\section{BILGI / INFO}

Geliş/Received: 22.01.2020

Kabul/Accepted: 29.05 .2020

Anahtar Kelimeler:

6360 sayılı büyükşehir yasası

Kırsal yerleşmeler

Konya

\section{Keywords:}

Metropolitan law no. 6360

Rural Settlements

Konya

*Sorumlu yazar/Corresponding author:

(B.Tuncer) btuncer0606@gmail.com

\section{DOI: $10.17211 /$ tcd. 678626}

\section{Atif/Citation:}

Tuncer, B. ve Bakırcı, M.(2020). 6360 sayılı büyükşehir yasasının Türkiye'nin kırsal yerleşim düzenine mevcut ve muhtemel etkileri: Konya örneği. Türk Coğrafya Dergisi (74), 75-85.

DOI:10.17211/tcd.678626

\section{ÖZ / ABSTRACT}

6360 Sayılı Büyükşehir Yasası, Türkiye'nin mevcut yerel yönetim sisteminde köklü bir değişim yaratmanın yanında, kırsal yerleşim düzenini doğrudan etkileyen birçok değişime de neden olmuştur. Yasanın uygulanmaya başlanmasıyla birlikte Türkiye'de kırsal yerleşim birimleri ve kırsal nüfus ile ilgili kavramların içeriği değişmiş ve ikili bir yapı oluşmuştur. Yasanın çıkarıldığı 2012 yılında kırsal nüfusun Türkiye toplam nüfus içindeki oranı \% 22,7 iken, 2014 yılında bu oran \% 8,2'ye, 2019 yılında ise \% 7,2'ye gerilemiştir. Bu çalışmanın amacı Türkiye'nin en geniş yüzölçümüne (40 838 km²) sahip ili olan Konya'da 6360 Sayılı Büyükşehir Yasası'nın kırsal yerleşim düzeni üzerindeki mevcut ve muhtemel etkilerini ortaya koymaktır. 6360 Sayılı Kanunla birlikte Konya İlinde 296'sı orman köyü olmak üzere toplamda 585 köy ve 175 belde belediyesinin tüzel kişiliği kaldırılarak mahalleye dönüştürülmüş, toplam mahalle sayısı 760’a çıkmıştır. Araştırmamızın dayandığı kavramsal temelleri ortaya koyabilmek adına öncelikle 6360 Sayılı Kanun ile ilgili konular için geniş bir literatür çalışması yapılmıştır. Ayrıca, Kanunun kırsal alandaki etkilerini somut olarak ortaya koyabilmek amacıyla farklı zaman dilimlerinde araştırma sahasında arazi çalışmaları yapılmış, Konya'nın uzak ilçeleri olan Yunak (156 km) ve Hüyük (95km) ile yakın ilçelerinden Sarayönü (39 km) ve Altınekin (55km) ilçelerinin kırsal mahallelerinde anket ve mülakatlar yapılmıştır. Kaynaklardan ve saha çalışmalarından elde edilen bilgiler amaç doğrultusunda yorumlanmış ve 6360 Sayılı Yasa'nın kırsal yerleşim düzeni üzerindeki olumlu-olumsuz etkileri tespit edilmeye çalışılmıştır. Yapılan tespitler neticesinde adı geçen yasanın uygulanmasına yönelik olumlu görüşler olduğu gibi, olumsuz düşüncelerin de var olduğu ortaya konulmuştur.

In addition to creating a radical change in the existing local government system of Turkey, the Metropolitan Law No. 6360 has also caused many changes that directly affect the rural settlements. With the start of implementation of the Act, rural settlements and concepts related to the content of the rural population in Turkey has changed and forming a dual structure. While the rural population rate was $22.7 \%$ in 2012 in Turkey's total population, before the law adopted, it is declned to $8.2 \%$ in 2014 and $7.2 \%$ in 2019. The purpose of this study is to reveal current and prospective effects of metropolitan law (no. 6360) on Turkey's rural settlements layout as a case study of Konya Province which has the largest surface area $\left(40838 \mathrm{~km}^{2}\right)$ in Turkey. With the Law no. 6360, the legal entity of 585 villages and 175 municipalities in Konya, 296 of which are forest villages, was abolished and transformed into neighborhoods and the total number of neighborhoods increased to 760. In order to reveal the theoretical foundations on which the research is based, a large literature study on Law No. 6360 has been conducted. In addition, in order to present the effects of the Law in the rural areas, field studies have been carried out in the research area in different time, surveys and interviews were conducted in the remote districts of Konya such as Yunak (156 km) and Hüyük (95 km), and nearby districts such as Sarayönü (39 km) and Altinekin (55 km). The information obtained from the sources and field studies were interpreted for the purpose and the positive and negative effects of Law No. 6360 on the rural settlements were tried to be determined. As a result of the findings, it was revealed that there are positive opinions about the implementation of the law as well as negative opinions. 


\section{Giriş}

“Insan-mekân etkileşiminin yoğun olarak gerçekleştiği yerleşmeler, her zaman yönetsel alanların temel unsuru olmuşlardır. Yerleşmelerin özelde yönetimleri tek tek yerel organlarca (belediye, muhtarlık) yürütülürken, genelde yönetimleri belirlenen bir merkez etrafinda toplanmak suretiyle mülki idare tarafindan yürütülmektedir. Her iki durumda da yerleşmeler yönetilen yerlerin odak noktasını oluşturmuşlardır (Özçağlar, 2015:115)". Türkiye'de yönetim açısından Büyükşehir olgusu çok eski değildir. Cumhuriyetin ilan edilmesinden sonra Türkiye'de modern anlamda yapılan ilk nüfus sayımı 1927 yılında gerçekleştirilmiştir. Toplam 13.648.270 olarak sayılan ülke nüfusunun \% 75,8'inin (10.342.391 kişi) kırsal yerleşim birimlerinde yaşadığı belirlenmiştir (TÜiK 2020). Bu durum kırsal alanlarının geliştirilmesine yönelik düzenlemeler yapmayı gerekli kılmıştır. Artan nüfusa bağlı olarak şehirleşmenin gelişmesi sonraki dönemlerde büyükşehir belediyelerinin kurulmasını zorunlu hale getirmiştir. Türkiye'deki illere, belediyelere ve köylere tüzel kişilik ilk olarak 1982 Anayasasının 127. maddesi gereğince verilmiştir (Kalpaklıŏlu, 2017:13). Bu düzenleme büyük yerleşim birimlerinde özel yönetim biçimlerinin uygulanmasına imkân sağlamıştr. Belirtilen kapsamda ilk olarak 1984 yılında çıkarılan 3030 Sayılı Kanunla İstanbul, Ankara ve İzmir büyükşehir olmuştur. Sonraki yıllarda başka iller de bu kapsama alınmış, 1986 yılında 3306 Sayılı Kanunla Adana, 1987 yılında 3391 Sayılı Kanunla Bursa, 3398 Sayılı Kanunla Gaziantep ve 3399 sayılı Kanunla da Konya büyükşehir olmuştur. 1988 yılında Kayseri (3508 Sayılı Kanun);1993 yılında Antalya, Diyarbakır, Erzurum, Eskişehir, İzmit, Mersin, Samsun (504 Sayılı KHK); 2000 yılında Adapazarı (593 Sayılı KHK); 2012 yılında 6360 Sayılı Yasa ile Aydın, Balıkesir, Denizli, Hatay, Manisa, Kahramanmaraş, Mardin, Muğla, Tekirdağ, Trabzon, Şanlıurfa ve Van; 2013 yılında 6447 Sayılı Kanunla Ordu büyükşehir belediyesi olmuştur (Tablo 1, Şekil 1). Böylece Büyükşehir statüsündeki il sayısı 30’a ulaşmıştır.

Tablo 1. Türkiye'de büyükşehir belediyelerinin tarihsel gelişimi Table 1. The historical development of the metropolitan municipalities in Turkey

\begin{tabular}{|c|c|c|}
\hline $\begin{array}{l}\text { Ylllar } \\
\end{array}$ & Yasal Düzenlemeler & Büyükşehir'e Dönüșen Belediyeler \\
\hline 1984 & 3030 Sayli Yasa & İstanbul, Ankara, İzmir \\
\hline 1986 & 3306 Saylh Yasa & Adana \\
\hline 1987 & $\begin{array}{l}3391,3398 \text { ve } 3399 \\
\text { Sayili Yasa }\end{array}$ & Bursa, Gaziantep, Konya \\
\hline 1988 & 3508 Sayılh Yasa & Kaysen \\
\hline 1993 & $\begin{array}{l}504 \text { Sayll Kanun } \\
\text { Hükmünde Karamame }\end{array}$ & Antalya, Diyarbakır, Erzunum, Eskişehir, İzmit, Mersin, Samsun \\
\hline 2000 & $\begin{array}{l}504 \text { Sayll Kanun } \\
\text { Hükmünde Karamame }\end{array}$ & Adapazarı (Sakarya) \\
\hline 2012 & 6360 Sayilh Yasa & $\begin{array}{l}\text { Aydın, Balıkesir, Denizli, Hatay, Manisa, Kahramanmaraş, Mardin, } \\
\text { Muğla, Ordu, Tekirdağ, Trabzon, Şanluurfa ve Van }\end{array}$ \\
\hline 2013 & 6447 Sayılh Yasa & Ordu \\
\hline
\end{tabular}

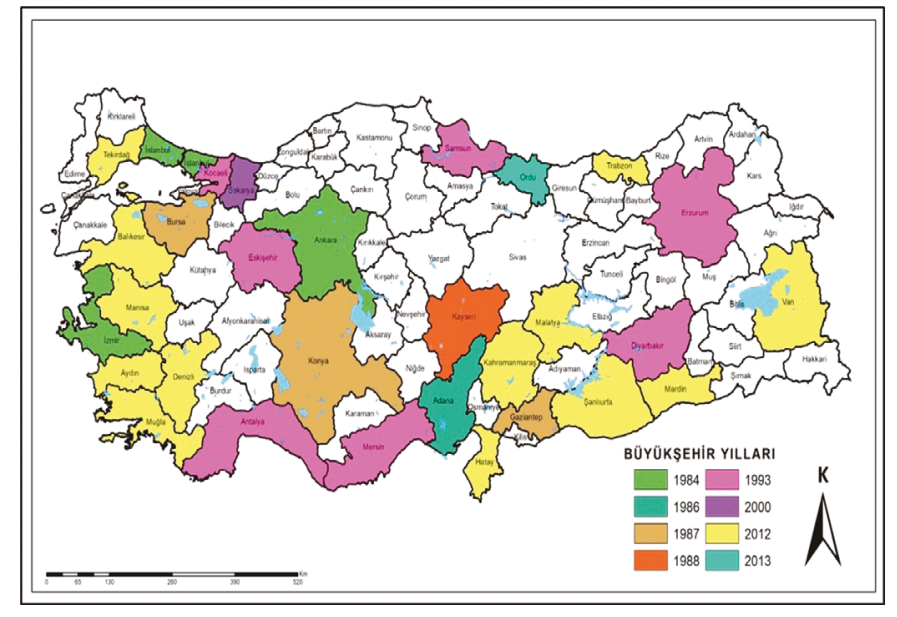

Şekil 1. Türkiye'nin büyükşehir belediyeleri ve kuruluş yılları Figure 1. According to the establisment year of metropolitan municipalities in Turkey

Özellikle, 12 Kasım 2012 tarihinde Türkiye Büyük Millet Meclisi'nde kabul edilen 6360 Sayılı Kanun yerel yönetim mevzuatnda büyükşehir belediyeleri ile ilgili çok önemli değişikliklere sebep olmuştur. 30 Mart 2014 tarihinde gerçekleştirilen yerel seçimlerden sonra uygulamaya geçen 6360 Sayılı Kanun ile Türkiye'de özellikle yerel yönetim açısından ikili bir yapı ortaya çıkmış, Büyükşehir'e dönüşen illerin yönetim yapısında ciddi değişiklikler meydana gelmiştir. Belirtilen Kanunla birlikte 14 ilde yeni büyükşehir ve bu şehirler bünyesinde 25 yeni ilçe kurulmuştur. Böylelikle il mülki sınırları aynı zamanda büyükşehir belediyelerinin de sınırı olmuştur. Büyükşehir'e dönüşen illerde il özel idare müdürlükleri kapatılmış, köy ve kasabalar ise mahallelere dönüştürülerek mevcut tüzel kişilikleri kaldırılmıştır. Bu şekilde büyükşehir statüsündeki illerde sadece büyükşehir belediyesi ve Büyükşehir'e bağlı ilçe belediyeleri kalmıştır (Göküş ve Alptürkler, 2016). Büyükşehir statüsüne kavuşan illerde 1089 belde belediyesi ile 16545 köyün tüzel kişiliği sona ererken, geri kalan diğer illerde nüfusu 2000'den aşağı olan 559 belde belediyesi ise kapatılmıştır.

6360 Sayılı yasa kapsamında ayrıca; "tüzel kişilikleri kaldırılarak Mahalleye dönüştürülen köylere ait menkul ve gayrimenkuller büyükşehir belediyelerine devredilmiş, yine Büyükşehir belediye sınırları dâhilinde bulunan ve tüzel kişiliği kaldırılarak mahalleye dönüştürülen beldelerin de mal varlıklarının tamamı ve personeli komisyon kararıla büyükşehir belediyelerine devredilmiştir. Kanun öncesinde kırsal yerleşim birimlerine hizmet götürülmesinde önemli kararların alındığı il genel meclislerinin de görevlerine son verilmiştir (Kalpaklıoğlu 2017:17-18)".

6360 Sayılı Büyükşehir Yasası, sadece genel yönetim açısından değil, aynı zamanda kırsal yerleşim düzeni açısından da radikal dönüşümlerin yaşanmasına zemin hazırlamıştır. Yasanın ardından Türkiye'de kırsal yerleşim alanları ve kırsal nüfus ile ilgili kavramların içeriği değişmiş ve ikili bir yapı oluşmuştur. Büyükşehir statüsünde olan illerde tüm nüfusun şehir nüfusu olarak kabul edilmesi ilk nüfus sayımından itibaren resmi istatistiklere yansıyan kırsal şehirsel ayırımında değişim yaşanmasını beraberinde getirmiştir. Türkiye'nin toplam nüfusu içindeki kırsal nüfus oranı yasanın çıkarıldığı 2012 yılında \% 22,7 iken, 2014 
yılında \% 8,2'ye gerilemiştir. 2012'de \% 77,3 olan şehirsel nüfus oranı ise 2014 'de \% 91,8'e yükselmiştir. Türkiye İstatistik Kurumu 2019 yılı verilerine göre Türkiye toplam nüfusunun (83 milyon) \% 7,2'sini kırsal nüfus oluştururken \% 92,8'ini ise şehirsel nüfus teşkil etmiştir.

Yasayla birlikte ortaya çıkan yeni durumun etkisi sadece istatistik rakamların değişimi üzerine olmamış, aynı zamanda planlama, hizmet sunumu, iktisadi, toplumsal ve siyasal açıdan da birçok dönüşümün yaşanmasına zemin hazırlamıştır. Yasaya rağmen köy olgusunun devam etmesi, yani köylerin halen kırsal nüfusun toprak üzerinde yoğunlaştğı yerler olması, bulundukları alanda üretimlerine devam etmeleri, sanayinin ticaretin ve meslek gruplarının bulunmaması ama buna karşılık sadece yönetsel anlamda kentlileşmeleri, birçok belirsizliği ve sorunu beraberinde getirmektedir (Susta ve Gülçulbulak, 2016). Büyükşehir belediyelerinin hizmet alanlarına kırsal yerleşimlerin dâhil olmasıyla hizmet alanları genişlemiş ve artan sorumluluklarla birlikte, kanuna uygun bir şekilde hizmetleri yerine getirmek ciddi sorunlara neden olmuştur.

Kuşkusuz Türkiye'de yasayla büyükşehir olarak ilan edilen illerin fiziki ve beşeri koşulları birbirinin aynı değildir. Her biri farklı büyüklükte yüzölçümüne, topografik koşullara ve kırsal yerleşim ünitesi sayısına sahip olmaları nedeniyle hizmet götürülmesi bakımından farklılıkların ortaya çıkması kaçınılmaz görünmektedir. Sayılan hususlara ek olarak, Büyükşehir statüsündeki belediyelerin idari yapılanması, kırsal alana bakış açısı ve hizmet götürme bakımından donanımı belirleyici diğer faktörler olmaktadır. Dolayısıyla farklı Büyükşehirlerde bu etkileşim düzeyinin ortaya konulması önem arz etmektedir. Daha önce Büyükşehir Kanununun genel olarak kırsal yerleşmeler üzerindeki etkisini ele alan çalışmaların yanı sıra bir Büyükşehir özelinde bu etkileşimi ortaya koyan çalışmalar da gerçekleştirilmiş bulunmaktadır (Kırmızı, 2019; Susta Olgun, 2018; Şenol, 2019, Bulut ve Dönmez, 2019; Gürbüz vd. 2014; Kut Görgün ve Yörür, 2017). Bu çalışmada ise Konya Büyükşehir Belediyesi sınırları içinde yer alan kırsal yerleşmelerin belirtilen yasal düzenleme sonrası karşı karşıya olduğu yeni durum analiz edilmeye çalışılmıştır.

\section{Materyal ve Yöntem}

Bu çalışmada, Türkiye'nin en geniş yüzölçümüne $(40838$ km²) sahip ili Konya'da 6360 Sayılı Büyükşehir Yasası'nın kırsal yerleşim düzeni üzerindeki mevcut ve muhtemel etkilerini ortaya koymak amaçlanmıştır. Çalışma esas olarak gözlem, anket ve veri analizi şeklinde yapılandırılmıştır. Araştırmanın dayandığı kavramsal temelleri ortaya koyabilmek adına öncelikle 6360 Sayılı Kanun ile ilgili konular için geniş bir literatür çalışması yapılmıştır. Literatür çalışması, mevcut yasanın içinde yer aldığı monografik çalışmaların derlenmesi ve değerlendirilmesiyle meydana getirilmiştir. Farklı zaman dilimlerinde (16.04.201924.04.2019 ve 20.05.2019) araştırma sahasında arazi çalışmaları yapılmış, Konya Büyükşehir Belediyesi'nden gerekli veriler alınmış, Konya'nın en uzak ilçelerinden olan Yunak (156 km) ve Hüyük (95) ile yakın ilçelerinden Sarayönü (39 km) ve Altınekin $(55 \mathrm{~km}$ ) ilçelerinde anket yapılmıştır. Adı geçen 4 ilçeye bağlı 20 kırsal mahallede 100 kişiye anket uygulanmıştır. Anket yapılan kırsal mahallelerin bağlı olduğu ilçeler seçilirken farklı uzaklıkta olmalarına dikkat edilmiştir. İlçelerin yakın ve uzak mesafelerden seçmemizdeki temel amaç büyükşehir belediyesinden hizmet alırken mesafe faktörünün etkisini analiz edebilmektir. Ankete katılanların cinsiyeti açısından bir denge hedeflemiş olmakla birlikte yöre kırsal yerleşmelerinin karakteri gereği kadın katılımcıların sayısı daha düşük oranda kalmıştır. Bu bakımdan ankete katılanların \%15'i kadın, \%85'i erkek olurken, genel yaş ortalaması ise 40,1 şeklinde gerçekleşmiştir. Anket katılımcıları rastlantısal olarak belirlenmiştir. Ankete katilım konusunda herhangi bir ön koşul belirlenmemiş olmakla birlikte, çalışma yaşında olan bireylere uygulanması hedeflenmiştir. Anket sonuçlarının değerlendirilmesinde excel programında tablo ve grafikleştirme ile oransal bir değerlendirme tercih edilmiştir. Ayrıca herhangi bir istatistiksel analiz programı kullanılmamıştır.

Saha çalışmalarında anket sorularına paralel soruları içeren ve sohbet şeklinde mülakatlar gerçekleştirilmiştir. Bahsi geçen görüşmeler sonucunda elde edilen bilgilerden anketleri destekleme amaçlı olarak yararlanılmış ve bulgular bölümünde çalışmanın sonuçları analiz edilmiştir. Son olarak kaynaklardan ve saha çalışmalarından elde edilen bilgiler amaç doğrultusunda yorumlanmış ve 6360 Sayılı Yasa'nın kırsal yerleşim düzeni üzerindeki olumlu-olumsuz etkileri tespit edilmeye çalışılmıştır.

\section{Bulgular}

3.1. Araştırma Alanının Konumu ve Belediyeciliğin Tarihsel Gelişim Süreci

Osmanlı'da Illk belediye teşkilat Tanzimat Dönemi'nde başlayan yenileşme sürecinde İstanbul'da kurulan Şehremaneti (1854) ile başlamıştır. Merkezi yönetimin yükünü hafifletmek amacıyla İstanbul dışında belediye hizmetlerinin (altyapı, temizlik, itfaiye, aydınlatma, çarşı ve pazar işleri gibi.) yapılabilmesi adına 1864 yılında yayınlan Vilayet Nizamnamesi önemli bir adımdır. Konya belediyesi hakkında ilk resmi kayıtlara 1864 Vilayet Nizamnamesinden dört yıl sonra yayınlanan 1868 tarihli Konya vilayet salnamesinde rastlanmaktadır. İstanbul dışındaki yerleşim birimlerinde batılı tarzda ilk belediye teşkilatlanmasının temeli ise 1871 yılında yayınlanan "Idare-i Umumiye-i Vilayat Nizamnamesi" ile atılmıştır. Bu nizamname taşradaki belediye teşkilatlarının yasal zeminini hazırlamış, vilayet, sancak ve kaza belediyelerinde yapılacak işlerle ilgili belediye meclislerinin oluşturulması amaçlanmıştır (Ortaylı,2000; Uyar,2004; Eryılmaz,2006; Yörükoğlu, 2009).

Belediyelerin hukuki statülerinin belirginleşmesi 1877 yılında "Dersaadet Belediye Kanunu" ile birlikte yürürlüğe giren "Vilayetler Belediye Kanunu" belirginleşmiştir; devlet belediye başkanını belediye meclisi üyeleri arasından seçerek tayin etmiştir. Yine bu kanunla, demokratik yönetimlerin vazgeçilmez unsuru olan gizli oylama ve açık tasnif sistemi uygulanmaya başlanmıştr. Konya Belediyesi'nin görev ve sorumlulukları da 1877 yılında yürürlüğe giren "Vilayetler Belediye Kanunu" çerçevesinde düzenlenmiştir (Ortaylı, 2000; Eryılmaz, 2006; Oktay, 2008).

1930 yılında çıkartılan Belediye Kanunu (1580 Sayılı) ve Umumi Hıfzısıhha Kanunu (1593 Sayılı) ile nüfusun yoğun olarak bulunduğu yerlerin sorumluluğu belediyelere verilmiştir. 1933 yılında yürürlüğe giren Belediyeler Yapı ve Yollar Kanunu (2290 Sayılı) Cumhuriyet tarihi içerisinde belediyecilik alanında yapılan 
önemli düzenlemeler arasındadır. Türkiye Cumhuriyeti'nin kuruluşundan itibaren tam 40 yıl boyunca valiler aynı zamanda belediye başkanı olarak da görev yapmışlardır. Bu uygulama 1963 yılında çıkarılan 307 Sayılı yasa ile son bulmuştur. 307 Sayılı yasayla belediye başkanlarının seçimle halk tarafindan iş başına getirilmesi kararlaştırılmıştır (Öztürk, 2014). 307 Sayılı Kanun gereğince ilk defa 1963 yılında yapılan mahalli idareler seçiminde belediye başkanları halk tarafindan seçilmiştir (Sevinç, 2015).

Konya Belediyesi, "1987 tarih 3399 Sayılı Kanunla” büyükşehir olmuştur. Selçuklu, Karatay ve Meram merkez ilçelerinden oluşan Konya Büyükşehir Belediyesi, 1989 yılından günümüze kadar belediye hizmetlerini bu statüye göre yürütmüştür. 2012 yılında çıkarılan 6360 Sayılı Kanun'la 2014 yılında Konya Büyükşehir Belediyesi'nin sınırı, Konya ilinin mülki sınırı olmuştur. Bu sınırlar içerisinde bulunan belde belediyeleriyle köy tüzel kişi likleri kaldırılarak, köyler ve beldeler mahalleye dönüştürülmüştür.

Konya, yaklaşık 40838 km2 yüzölçümü ile Türkiye'nin en geniş ve 2205609 nüfusuyla en kalabalık yedinci ilidir. Ortalama yükseltisi 1016 m'dir. İdari olarak, kuzeyden Ankara, güneyden Mersin ve Karaman, doğudan Aksaray ve Niğde, batıdan da Eskişehir, Afyonkarahisar, Isparta ve Antalya illeri ile çevrelenmektedir (Şekil 2).

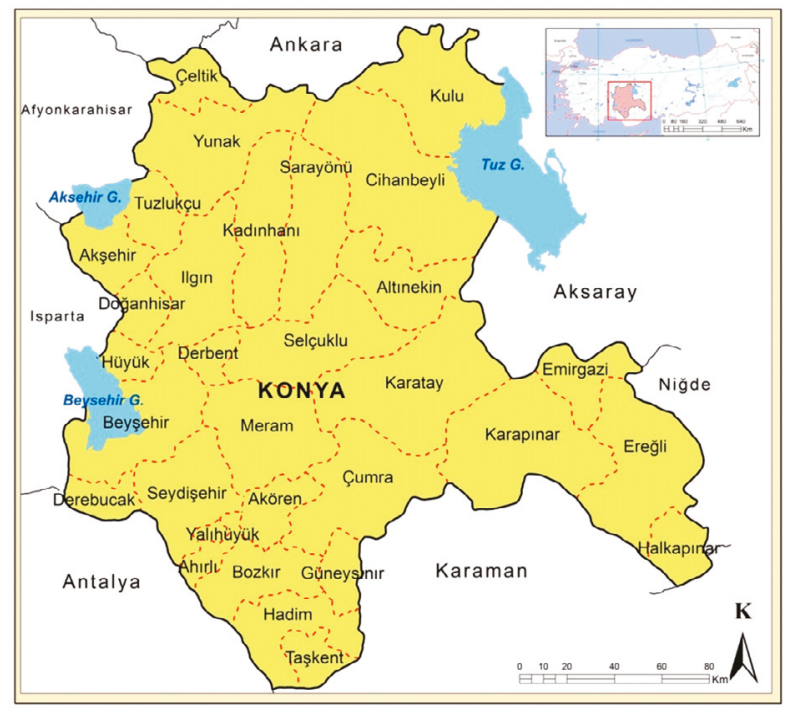

Şekil 2. Konya İli Lokasyon Haritası

Figure 2. Location Map of Konya Province.

3.2. 6360 Sayılı Büyükşehir Yasası'nın Ortaya Çıkardığı Yeni Durum

Araştırmamızın asıl konusuna geçmeden önce kırsal yerleşimler ve kırsal nüfusun tanımlanması faydalı olacaktır. Türkiye'de yerleşmelerle ilgili idari sınıflandırmanın nasıl yapılacağı kanunlarla belirlenmiş olmasına rağmen, coğrafi faktörlerin bu sınıflandırmadaki etkisinin önemsenmediği görülmektedir. Yerleşme biriminin statüsü şehirse o yerleşmenin nüfusu şehirsel nüfus ya da kırsal statüde bir yerleşme ise kırsal nüfus olarak kabul edilmektedir. Bu değerlendirmede kimi araştırmacılar nüfus sayısını esas alırken kimisi nüfusun ekonomik faaliyet kollarına göre dağılımına bakmaktadır. TUík ise il ve ilçe merkez nüfuslarının tamamını şehirsel, diğer tüm yerleşim birimlerinin nüfuslarını ise kırsal nüfus olarak değerlendirmektedir (Özçağlar 2015; Yılmaz, 2015; Taş, 2017).
Türkiye toplam nüfusu ve kentsel nüfus miktarı 1927'den 2012 yılına kadar olan dönemde sürekli olarak artmıştır. Buna karşılık, 1927 ve 1980 yılları arasında sürekli artış gösteren kırsal nüfus miktarı, 1980 yılında Türkiye Cumhuriyeti tarihindeki en yüksek seviyeye çıkmış (25 milyon), sonraki yıllarda ise dalgalı bir seyir izlemiştir. 1980 yılında 25 milyon olan kırsal nüfus miktarı, 2012 yılına gelindiğinde \%32'lik bir azalmayla 17 milyona inmiştir. Bu düşüşteki en önemli etken geçen 32 yıllık dönemde köyden kente yapılan yoğun göçler, idari sınıflandırmalar ve yasa değişiklikleridir.

Konya ilinde 1927-1985 yılları arasında kırsal nüfus miktarı sürekli olarak artış göstermiş, 1990 - 2000 yıllarından 2012 yılına kadar ise belirgin bir şekilde düşmüştür. Konya'da 1985 yılında 916593 kişiyle (Toplam nüfusa oranı \% 51,81) en yüksek seviyesine ulaşan kırsal nüfus miktarı 2012 yılına gelindiğinde yaklaşık \% 53'lük bir azalmayla 488 418'e düşmüştür (Tablo 2). Ancak mevcut azalmaya rağmen belirtilen yıl Konya ili kırsal nüfus miktarı bakımından İç Anadolu Bölgesi illeri arasında ilk sırada yer almış, Türkiye genelinde ise Şanlıurfa, Hatay, Antalya ve Van illerinden sonra kırsal nüfus oranı en yüksek beşinci il olmuştur.

Tablo 2. 6360 sayılı yasa öncesi Konya ili kırsal ve kentsel nüfusu Table 2. Rural and urban population of Konya province before the law no. 6360

\begin{tabular}{|c|c|c|c|c|c|}
\hline \multirow[t]{2}{*}{ Saym Yilları } & \multicolumn{3}{|c|}{ Nüfus Miktan } & \multicolumn{2}{|c|}{ Toplam Nüfusa Oranı (\%) } \\
\hline & Toplam & Şehirsel & Krrsal & Șehirsel & Krrsal \\
\hline 1927 & 504125 & 100.946 & 403.179 & 20 & 80 \\
\hline 1935 & 569684 & 114.051 & 455.633 & 20 & 80 \\
\hline 1940 & 620936 & 129.045 & 491.891 & 21 & 79 \\
\hline 1945 & 661877 & 139877 & 522.000 & 21 & 79 \\
\hline 1950 & 741026 & 157421 & 583.605 & 21 & 79 \\
\hline 1955 & 847723 & 214896 & 632.827 & 25 & 75 \\
\hline 1960 & 982422 & 279.878 & 702.544 & 28 & 72 \\
\hline 1965 & 1122622 & 354.578 & 768.044 & 31 & 69 \\
\hline 1970 & 1280239 & 455.707 & 824.532 & 36 & 64 \\
\hline 1975 & 1422461 & 555.172 & 867.289 & 39 & 61 \\
\hline 1980 & 1562139 & 672.695 & 889.444 & 43 & 57 \\
\hline 1985 & 1769050 & 852.457 & 916.593 & 48 & 52 \\
\hline 1990 & 1750303 & 963.128 & 787.175 & 55 & 45 \\
\hline 2000 & 2.192 .166 & 1.294 .817 & 897.349 & 59 & 41 \\
\hline 2007 & 1959082 & 1.412 .343 & 546.739 & 72 & 28 \\
\hline 2008 & 1969868 & 1.423 .546 & 546.322 & 72 & 28 \\
\hline 2009 & 1992675 & 1.450 .682 & 541.993 & 72 & 28 \\
\hline 2010 & 2013845 & 1.486 .653 & 527.192 & 74 & 26 \\
\hline 2011 & 2038555 & 1.527 .937 & 510.618 & 75 & 25 \\
\hline 2012 & 2052281 & 1.563 .863 & 488.418 & 76 & 24 \\
\hline
\end{tabular}

Kaynak: Türkiye Istatistik Kurumu

2012 yılı verilerine göre Konya ili toplam nüfusu 2052 281'dir. 1987 yılında çıkan 3399 Sayılı Kanun ile büyükşehir statüsü kazanan Konya ili; 2012 yılı öncesinde 31 ilçe, 168 belde ve 584 köyden oluşmaktaydı. 2012 yılında hayata geçen 6360 Sayılı Büyükşehir Kanunu sonrasında 168 belde ve 584 köy mahalleye dönüştürülerek, mevcut tüzel kişilikleri sona erdirilmiştir. Kapatılan belde belediyeleri ve köylerdeki kırsal nüfus miktarı ise 488118 olmuştur (Tablo 3). 
Her ne kadar belirtilen yerleşmeler kanunla köy statüsünden kırsal mahalle statüsüne dönüştürülmüş olsa da bunlar yerleşme coğrafyası bakımından önceden olduğu gibi birer köy yerleşmesidir. Kanunla yapılan bu değişiklik, fonksiyonel bakımdan bu yerleşmelerin mevcut durumunu değiştirmiştir. Başka bir deyişle idari coğrafya anlamında bir değişiklik söz konusu olup, yerleşme coğrafyası bakımından önceki niteliklerinden farklı bir durum söz konusu değildir.

6360 Sayılı Büyükşehir Kanunu'nun yürürlüğe girmesiyle birlikte Konya Büyükşehir Belediyesi'nin hizmet alanı genişlemiş, Kırsal Hizmetler ve Koordinasyon Dairesi Başkanlığı tarafindan 31 ilçe ile 752 kırsal mahallesinde hızı bir reaksiyonla yatırım hamlesi başlatılmıştır. Ülkemizin en geniş alanlı yüzölçümüne sahip ilinde toplam 28 ilçeden 22'sinin il merkezine uzaklığının ortalama 70-150 km arasında olması büyükşehir belediyesine ciddi anlamda görev ve sorumluluklar yüklemiştir (Şekil 3).

Tablo 3. 6360 Sayılı Yasa Öncesi ve Sonrası Konya İli İdari Durumu Table 3. Administrative Status of Konya Province Before and After the Law No. 6360

\begin{tabular}{|c|c|c|c|c|c|c|c|c|}
\hline No & Belediyeler & $\begin{array}{l}\text { Belde } \\
\text { Sayrs } \\
\end{array}$ & $\begin{array}{c}\text { Köy } \\
\text { Sayıs }\end{array}$ & $\begin{array}{l}\text { Toplam } \\
\text { Nüfus } \\
\text { (2012) }\end{array}$ & $\begin{array}{c}\text { Yüzölẹümü } \\
\left(\mathbf{k m}{ }^{2}\right)\end{array}$ & $\begin{array}{c}\text { Kapattlan } \\
\text { Belde ve } \\
\text { Köy Sayss } \\
\end{array}$ & \begin{tabular}{|c|} 
Kapatilan \\
Belde ve Köy \\
Nüfusu \\
\end{tabular} & \begin{tabular}{|c|} 
Konya II \\
Merkezine \\
Uzakhğı $(\mathrm{km})$ \\
\end{tabular} \\
\hline 1 & Büyükşehir & - & & & & & & \\
\hline 2 & Karatay & 4 & 25 & 275987 & 2832 & 29 & 19532 & - \\
\hline 3 & Meram & 6 & 22 & 326444 & 1822 & 28 & 15132 & 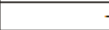 \\
\hline 4 & Selçuklu & 3 & 20 & 552110 & 1931 & 23 & 11991 & 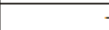 \\
\hline 5 & Ahurh & 1 & 10 & 4867 & 325 & 11 & 4038 & 77 \\
\hline 6 & Akören & 2 & 8 & 6891 & 640 & 10 & 3563 & 47 \\
\hline 7 & Akşehir & 11 & 23 & 94575 & 895 & 34 & 32521 & 108 \\
\hline 8 & Altmekin & 3 & 14 & 14274 & 1312 & 17 & 10638 & 59 \\
\hline 9 & Beyşehir & 18 & 37 & 69739 & 2054 & 18 & 33867 & 70 \\
\hline 10 & Bozkir & 10 & 38 & 28937 & 1105 & 55 & 21197 & 78 \\
\hline 11 & Cihanbeyli & 13 & 20 & 57243 & 3702 & 33 & 41277 & 96 \\
\hline 12 & Çeltik & 2 & 6 & 10475 & 640 & 8 & 6407 & 182 \\
\hline 13 & Çumrs & 10 & 30 & 64126 & 2089 & 40 & 33946 & 42 \\
\hline 14 & Derbent & 1 & 6 & 4859 & 359 & 7 & 2287 & 44 \\
\hline 15 & Derebucalk & 4 & 4 & 8049 & 451 & 8 & 5661 & 136 \\
\hline 16 & Doğanhisar & 8 & 8 & 18904 & 482 & 16 & 13186 & 77 \\
\hline 17 & Emirgazi & 2 & 7 & 9451 & 798 & 9 & 4424 & 119 \\
\hline 18 & Ereğli & 6 & 44 & 137038 & 2214 & 50 & 38375 & 144 \\
\hline 19 & Güneysmur & 2 & 12 & 10064 & 482 & 24 & 5327 & 70 \\
\hline 20 & Hadim & 6 & 22 & 14579 & 1165 & 28 & 11506 & 98 \\
\hline 21 & Halkapmar & - & 12 & 4930 & 605 & 12 & 3162 & 168 \\
\hline 22 & Hüyük & 10 & 9 & 17328 & 443 & 19 & 13945 & 78 \\
\hline 23 & Ilgn & 7 & 36 & 57148 & 1636 & 43 & 25320 & 68 \\
\hline 24 & Kadmhanı & 4 & 37 & 33442 & 1568 & 41 & 19839 & 48 \\
\hline 25 & Karapmar & 4 & 14 & 48176 & 2623 & 18 & 15442 & 95 \\
\hline 26 & Kulu & 7 & 28 & 50525 & 2234 & 35 & 29275 & 145 \\
\hline 27 & Sarayönü & 6 & 12 & 26923 & 16201 & 18 & 18112 & 46 \\
\hline 28 & Seydişehir & 8 & 31 & 63639 & 1458 & 39 & 22815 & 74 \\
\hline 29 & Taşkent & 4 & 3 & 6967 & 457 & 7 & 5306 & 140 \\
\hline 30 & Tuzlukçu & - & 11 & 7199 & 704 & 11 & 3554 & 101 \\
\hline 31 & Yalhhüyük & - & 2 & 1787 & 94 & 2 & 172 & 72 \\
\hline \multirow[t]{2}{*}{32} & Yunak & 6 & 30 & 25605 & 2101 & 36 & 16301 & 159 \\
\hline & Toplam & 168 & 584 & 2052281 & 41001 & 752 & 488118 & - \\
\hline
\end{tabular}

Kaynak: Türkiye Istatistik Kurumu

IIlçe merkezlerinin bile çok uzak mesafelerde olduğu il genelinde bir de bu ilçelere bağlı kırsal mahallelere ulaşmak ilk yıllar Konya Büyükşehir Belediyesi tarafindan büyük bir problem olarak görülmüştür. Özellikle ilin güneyinde Akdeniz Bölgesi'nde yer alan Taşkent (1620 m.), Hadim (1530 m.), Çarşamba çayının iki yamacına kurulmuş Torosların yüksek kesimlerinin bulunduğu Bozkır (1125 m.) ve Bat Torosların Gembos Polyesi Havzası'nda bulunan Derebucak (1240 m.) ilçelerinin engebeli topoğrafik yapısından dolayı buraların kırsal mahallelerine hizmet götürme noktasında büyükşehir belediyesinin ciddi anlamda çözümler üretmesini gerektirmiştir.

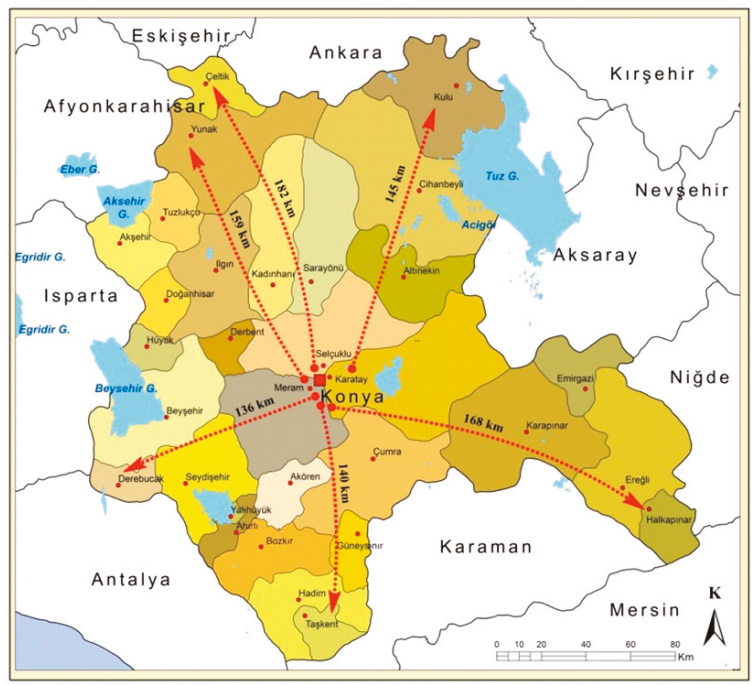

Şekil 3. Konya il merkezine göre en uzak ilçeleri örneklemi

Figure 3. Samples of the most remote districts according to Konya city center

6360 sayılı kanunun yürürlüğe girmesi ile birlikte büyükşehir belediyelerinin hizmet ölçeğinde ve çeşidinde ve/veya yoğunluğunda gerçekleşen değişim, söz konusu belediyelerin kurumsal ve yapısal olarak da belli bir değişime gitmelerini gerekli kılmıştır. Bu bağlamda, 6360 Sayılı Kanun ile birlikte kurumsal yapıda idari kapasiteyi geliştirmeye yönelik önemli adımlar atılmıştır. Tarımsal Hizmetler Daire Başkanlığı, Kırsal Hizmetler ve Koordinasyon Daire Başkanlığı, Muhtarlık Hizmetleri Şube Müdürlüğü oluşturulan yeni birimlerdir (Usta vd., 2018). Bu çerçevede Büyükşehir Belediyesi tarafindan, kırsal mahallelere daha hızlı ve etkin şekilde hizmet ulaştırılabilmek için Fen İşleri Daire Başkanlığına bağlı olarak il genelinde 7 adet bölge birimi hizmete sokulmuştur (Tablo 4). Hizmet bölgeleri, il merkezine en uzak ilçelerde çevresine göre merkezi konumda olan yerleşim birimlerine kurulmuş ve bu bölgelere hizmet binaları yapılarak (Şekil 4), iş makinaları ve çeşitli araç-gereçlerle donatılmıştir.

Konya ili genelinde, kırsal kesime hizmet götürme bakımından 6360 Sayılı Kanun öncesinden farklı bir model oluşturulmuş ve kurulan 7 Bölge Şefliği yoluyla kırsal mahallelere en kısa sürede ulaşılarak sorunların çözülmesine yönelik çözümler üretilmeye başlanmıştır (Şekil 5). Özellikle Tarımsal Hizmetler ve Koordinasyon Dairesi Başkanlığı tarafindan; kırsal mahallelerde bulunan çiftçilere eğitimler verilmesi, toprak etüdü, toprak ve su analizleri, organik tarım ve iyi tarım destekleri, bitkisel ve hayvansal üretimde kaliteyi arttırmak için projeler, küçük ölçekli tarım alet ve makinaları ile her türlü destek sağlamak gibi birçok konuda hizmetler sunulmuştur.

Tablo 4. Konya Büyükşehir Belediyesi Kırsal Hizmet Bölgeleri Table 4. Rural Service Areas of Konya Metropolitan Municipality

\begin{tabular}{|l|l|l|}
\hline Bölge No & Bölge Merkezi & Bölgeye bağhı İlçeler \\
\hline 1.Bölge & Karatay & Meram, Selçuklu, Karatay, Çumra \\
\hline 2.Bölge & Yunak & Yunak, Çeltik, Tuzlukçu \\
\hline 3.Bölge & Doğanhisar & Ilgın, Akşehir, Kadınhanı, Doğanhisar \\
\hline 4.Bölge & Beyşehir & $\begin{array}{l}\text { Derbent, Hüyük, Derebucak, Beyşehir, Seydişehir, } \\
\text { Yalihüyük, Ahırlı }\end{array}$ \\
\hline 5.Bölge & Bozkır & Hadim, Taşkent, Güneysmır, Bozkır, Akören \\
\hline 6.Bölge & Ereğli & Ereğli, Halkapınar, Karapınar, Emirgazi \\
\hline 7.Bölge & Cihanbeyli & Altınekin, Cihanbeyli, Kulu, Sarayönü \\
\hline
\end{tabular}




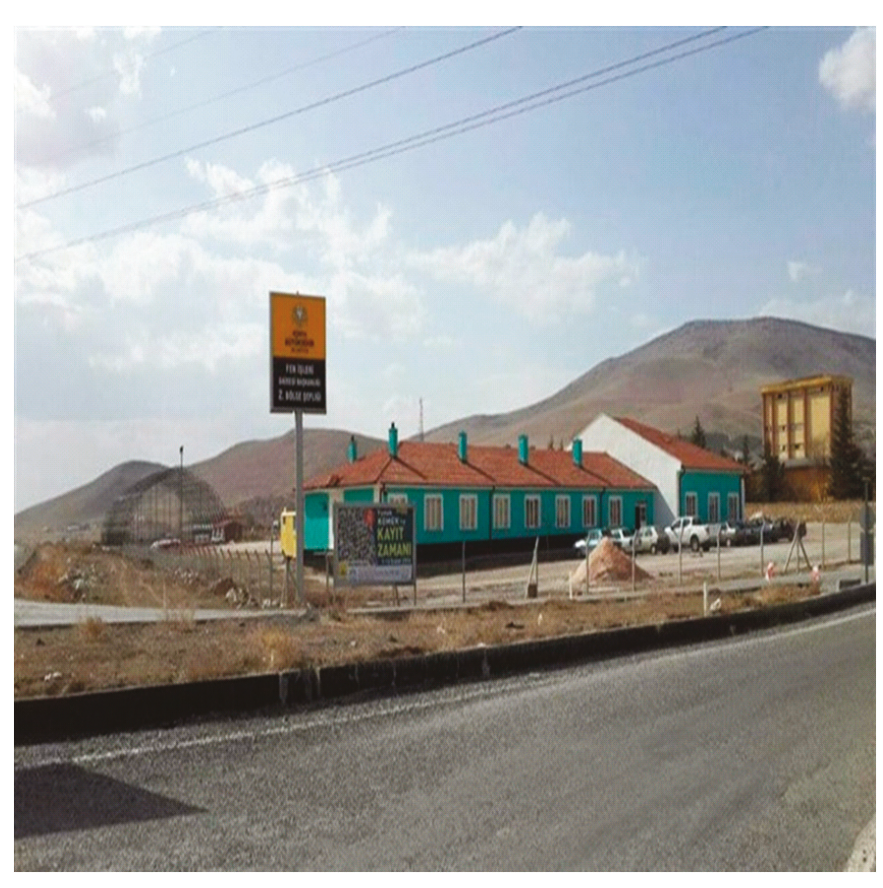

Şekil 4. Konya Büyükşehir Belediyesi Kırsal Hizmetler ve Koordinasyon Başkanlığı 2.Bölge Şefliği (Yunak)

Figure 4. 2nd Region Chief of Konya Metropolitan Municipality Directorate of Rural Services and Coordination (Yunak)

Konya Büyükşehir Belediyesi İmar ve Şehircilik Dairesi Başkanlığı İmar ve Kent Estetiği Şube Müdürlüğü tarafindan “6360 sayılı kanunla köyden mahalleye dönüşen ve imar planı bulunmayan" yerleşim sahiplerini bilgilendirmek için aşağıdaki soruların cevaplarından oluşan bir "Köyüm Mahalle Oldu" afişi hazırlanmıştır. Bu afişte, özellikle daha önce köy olup 6360 Sayılı Kanunun yürürlüğe girmesi ile birlikte mahalleye dönüşen yerlerde yaşayan vatandaşların söz konusu değişim karşısında sorun yaşamaları muhtemel konularda sorular sorarak onların olası sorunlarına çözüm üretmek amaçlanmıştır. Vatandaşların bu sorulara verilecek cevaplar ile yeni kanunun getirdiği değişikliklere uyumlarını sağlamak ve bu yolla memnuniyet düzeylerini arttırmak amaçlanmıştır (Usta vd., 2018). Hazırlanan afişte sorulan sorular şunlardır:

\section{- Parselimin imar durumunu öğrenmek için ne yapmalıyım?}

- Parselimin köy yerleşik alan sınırları içerisinde olduğunu öğrendim. Fakat imar planı veya köy yerleşme planı olmayan yerleşkemizde ev yapmak için ne yapmalıyım?

- Köy içerisindeki 200 metrekareden küçük parselime ne kadar büyüklükte ev yapılmasına izin verilir?

- 06.12.2012 tarihinden önce tamamlamış olduğum köy içerisindeki yapım için elektrik, su vb. kamu hizmetlerinden yararlanmak istiyorum. Ne yapmalıyım?

- Belediyemden parselimin köy dışında kaldığını öğrendim. Parselime kendi ihtiyacımı karşılamak için tarım ve hayvancılık amaçlı yapı yapmak istiyorum, ne yapmalıyım?

- Belediyemden parselimin köy dışında olduğunu ve yolu olmadığını öğrendim, ne yapmalıyım?

- Parselim köy içerisinde ve ev yapabileceğimi öğrendim, nasıl bir yol izlemeliyim?
- Köy içinde bulunan bakkalımın, ruhsatı, iş yeri çalışma izni olabilir mi? (Usta vd., 2018).

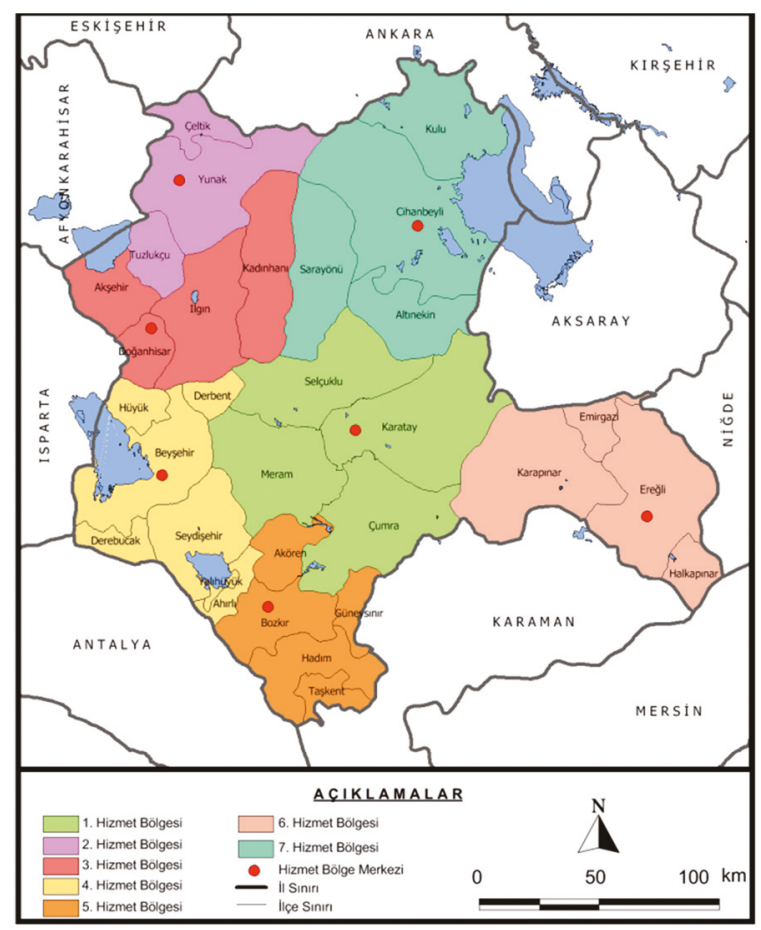

Şekil 5. Konya Büyükşehir Belediyesi Kırsal Hizmet Bölgeleri Haritası Figure 5. Map of Konya Metropolitan Municipality Rural Service Areas

Ayrıca Konya Büyükşehir Belediyesi Bilgi İşlem Dairesi BaşkanIığı tarafindan hizmete sunulan MUBis (Muhtar Bilgi Sistemi) ile merkez ve kırsal mahallelerde 1188 mahalle muhtarlığına internet ve bilişim-donanım hizmeti sağlanmıştır. MUBis sayesinde hiç bir prosedüre, dilekçeye ve yüz yüze görüşmeye gerek olmaksızın kırsal yerleşim birimlerinde yaşanan herhangi bir sıkınt muhtarlar tarafindan sisteme girilerek sorun belirtildiğinde en yakın bölge şefliği aracılığıyla en hızlı şekilde hizmet verilmektedir.

3.3. Araştırma Sahasında 6360 Sayılı Yasanın Mevcut ve Muhtemel Etkileri

\subsubsection{Katlımcıların profilleri ve anket uygulanan kırsal mahal-} leler

Çalışmamızda Konya il genelinde 4 ilçeye bağı 20 kırsal mahallede 100 kişiye anket uygulanmıştr. Ankete katılanların \%15'i kadın, \%85'i erkek olup, genel yaş ortalaması ise 40,1 'dir (Tablo 5).

Anket uygulanan dört ilçe merkezinin il merkezine ortalama uzaklığı 86 km'dir. Anketimiz Sarayönü (Başhöyük, Kurşunlu, Kadıoğlu, Ladik ve Boyalı mahalleleri), Altınekin (Oğuzeli, Mantar, Koçaş, Yenice ve Sarnıç mahalleleri), Hüyük (Burunsuz, Mutlu, İmrenler, Köşk ve Görünmez mahalleleri) ve Yunak (Böğrüdelik, Meşelik, Yavaşlı, Turgut ve Hacıfakılı mahalleleri) ilçelerinin kırsal mahallelerinde uygulanmıştır. 
Tablo 5. Katilımcıların Demografik Özellikleri

Table 5. Demographic Characteristics of Survey Participants

\begin{tabular}{|l|c|}
\hline Demografik Özellikler & $\%$ \\
\hline Cinsiyet & 15 \\
\hline Kadn & 85 \\
\hline Erkek & 2,3 \\
\hline Yas & 5,7 \\
\hline $18-25$ & 47,5 \\
\hline $26-35$ & 33,1 \\
\hline $36-45$ & 10,6 \\
\hline $46-55$ & 0,8 \\
\hline $56-65$ & \\
\hline $65+$ & 1,2 \\
\hline Eğitim & 49 \\
\hline Okur-Yazar olmayan & 33 \\
\hline Illkokul & 7 \\
\hline Ortaokul & 9,8 \\
\hline Lise & \\
\hline Üniversite & 78,4 \\
\hline Meslek & 6,6 \\
\hline Çiftçi & 3 \\
\hline Esnaf & 4 \\
\hline Kamu Görevlisi & 8 \\
\hline Serbest Meslek & \\
\hline Emekli & \\
\hline
\end{tabular}

\subsubsection{Katılımcıların 6360 sayılı büyükşehir kanunu hakkında} bilgi sahibi olma düzeyleri

Anket uygulanan katılımcıların \%81,6'sı 6360 Sayılı Büyükşehir Yasası ile ilgili yeterli bilgiye sahip olmadıklarını, detaylarını tam olarak bilmediklerini, \% 6'sı ise yasayla ilgili tam anlamıyla bilgi sahibi olduklarını ifade etmişlerdir. Katılımcıların \%2,4'ü ise yasayla ilgili hiçbir bilgiye sahip olmadıklarını belirtmişlerdir. Bilgi sahibi olduklarını belirten katılımcıların (\% 6) çoğunu mahalle muhtarları oluşturmaktadır (Tablo 6). Büyükşehir yasasının uygulamaya başlanmasının üzerinden yedi yıl geçmesine ve birçok konuda kırsal kesimi etkilemesine rağmen yasayla ilgili bilgi sahibi olanların sayısının çok az olması ciddi anlamda olumsuz bir durum arz etmektedir.

Tablo 6. 6360 Sayılı Büyükşehir Kanununun içeriği hakkında bilgi sahibi olma düzeyleri

Table 6.The level of knowledge about the content of the Metropolitan Law No. 6360

\begin{tabular}{|l|c|}
\hline 6360 Sayılı Büyükş̧ehir kanunu hakkknnda bilginiz var mı? & $(\%)$ \\
\hline Bilgi sahibi değilim & 2,4 \\
\hline Az bilgi sahibiyim & 81,6 \\
\hline Bilgi sahibiyim & 6 \\
\hline Toplam & $\mathbf{1 0 0}$ \\
\hline
\end{tabular}

3.3.3.Katılımcıların 6360 sayılı büyükşehir kanunu hakkındaki düşünceleri

Katlımcılara kanun hakkındaki düşünceleri sorulduğunda, \% 71,4 gibi yüksek bir oranda katlımcı olumlu görüş bildirirken, \%28,6'sı ise olumsuz görüş bildirmiştir. Olumlu görüş bildirenlerin tamamı köyden mahalleye dönüşen kırsal yerleşim birimlerinde ikamet eden katılımcılardan oluşurken, olumsuz görüş bildirenlerin tamamına yakını ise kapatılan eski belde belediyelerinde yaşayanlardan oluşmaktadır. Eski belde belediyesi iken köye dönüşen mahallelerde yaşayan katılımcılar yasaya şiddetle karşı çıkmakta olup, yasa öncesi dönemin çok daha iyi olduğunu belirtmişlerdir (Tablo 7). Bunun en önemli sebebi ise, geçmişte belediye tüzel kişilik sayesinde kendi ihtiyaçları doğrultusunda tasarrufta bulundukları taşınır-taşınmaz mallarını kullanma imkânının yasayla birlikte ortadan kalkmış olmasıdır.

Tablo 7. 6360 Sayılı Büyükşehir Kanunu hakkındaki düşünceler Table 7. Thoughts on the Metropolitan Law No. 6360

\begin{tabular}{|l|c|}
\hline Kanun hakkandaki genel düşünceniz nedir? & $(\%)$ \\
\hline Olumlu & 71,4 \\
\hline Olumsuz & 28,6 \\
\hline Toplam & 100 \\
\hline
\end{tabular}

\subsubsection{Katılımcıların 6360 sayılı yasaya göre köylerin mahalleye} dönüşümünü olumlu karşılama sebepleri

6360 Sayılı yasa öncesi köy yerleşmelerinde çöplerin toplanması ve kanalizasyon gibi altyapı hizmetleri söz konusu değilken, yasanın uygulamaya geçmesinden sonra mahallelerde haftada 2-3 kez çöplerin toplanması, kanalizasyon şebekesi döşenmesi, köy içi ve çevre yolların yapılması yasayı olumlu karşılayan katılımcıların önemle üzerinde durdukları konular arasındadır. Katılımcıların \% 19,5'i köy yollarının yapılmış olmasının, \% 27,6'sı çöplerin düzenli olarak toplanmasının, \% 25,4'ü alt yapı hizmetlerinin verilmesinin olumlu görüş bildirmelerinde en etkili nedenler olduğunu ifade etmişlerdir (Tablo 8).

Tablo 8. Köy yerleşmelerinin mahalleye dönüşmesini olumlu karşılama sebepleri

Table 8. The reasons for being evaluation positively of transformation the village settlements into neighborhoods

\begin{tabular}{|l|c|}
\hline $\begin{array}{l}\text { Köy yerleşmelerinin mahalleye dönüşmesini olumlu karşıllama } \\
\text { sebepleriniz nelerdir? }\end{array}$ & $(\%)$ \\
\hline Haftanın iki günü çöplerin toplanıyor olması & 27,6 \\
\hline $\begin{array}{l}\text { MUBi̇S sistemi sayesinde belediyenin hızlı ve etkili bir şekilde sorunlara } \\
\text { özetmesi }\end{array}$ & 23,6 \\
\hline Köy yollarmın yapıllmıs olması & 19,5 \\
\hline İçme ve kullanma suyu problemlerinin giderilmesi & 3,9 \\
\hline Alt yapı hizmetleri & 25,4 \\
\hline Toplam & $\mathbf{1 0 0}$ \\
\hline
\end{tabular}

Katlımcılar 6360 Sayılı Yasa sonrası MUBiS sitemi sayesinde sorunlarına hızlı ve etkili çözümler bulunduğunu belirtmişlerdir. "Bütün muhtarların cep telefonlarına MUBis uygulaması yüklendi. Herhangi bir sorunla karşılaştığımızda sorunları uygulamadan sisteme girerek aynı anda sorun metni büyükşehir belediyesinin sistemine düşüyor. Bazen sorunlarımı çabuk çözülürken bazen de büyükşehir sorumluluğu ilçe belediyesine yüklüyor, sonrasında da artık ilçe belediyesi soruna ne zaman çözüm üretir hiç bilmiyoruz (K8, 44 Yaş, Muhtar)".

\subsubsection{Katılımcıların 6360 sayılı yasaya göre köylerin mahalleye dönüşümünü olumsuz karşılama sebepleri}

Büyükşehir yasasına olumsuz görüş bildiren (\% 23,7) katılımcıların \% 60,1 gibi yüksek bir oranla yasayla ilgili en çok şikâyet ettikleri konu ev ve eklentileri (ahır, samanlık vs.) gibi inşaat yapma işlerinin ekonomik anlamda kendilerini çok zorlaması olmuştur. Katılımcıların $\% 25^{\prime} \mathrm{i}$ ise gelen su faturalarının il ve ilçe merkezlerindeki meskenlerle aynı tutarlarda olmasının kendilerini maddi anlamda olumsuz etkilediğini belirtirken, katılım- 
cılardan \% 11,3'üü (özellikle mahalle muhtarları) büyükşehir belediyesinin MUBis üzerinden bildirilen sorunların çözümü konusunda sürekli ilçe belediyesine yönlendirme yapmasını bir olumsuzluk olarak ifade etmişlerdir (Tablo 9).

Katlımcıların yasaya olumsuz bakmalarındaki en önemli sebep imar işlerinin maliyetinin çok artmasıdır. "6360 Sayılı Yasa uygulanmaya başlandıktan sonra Milli Eğitimden emekli olup köyüme geldim. Eski baba yadigârı evimizin yanına iki katlı bir ev yaptirmaya karar verdim. Büyükşehir belediyesinden imar izni, ruhsat parası, inşaatta çalışan işçilere sigorta yaptırma işi falan derken ekonomik anlamda tükendim. Yasadan önce çok kolay olan bu işler artık işin içinden çıkılmaz bir hâl aldı (K1,62 Yaş, Emekli Öğretmen)."

"Yasa öncesi ev yapacağımız zaman 250 lira vererek istediğimiz firmaya yaptırdığımız koordinatlandırma işini şimdi büyükşehir belediyesinin anlaşmalı olduğu harita mühendisliği firmasına 750 lira vererek yaptirmak zorundayız (K2, 47 Yaş, Çiftçi)"

Tablo 9. Köy yerleşmelerinin mahalleye dönüşmesini olumsuz karşılayanların sebepleri

Table 9. The reasons for being evaluation negatively of transformation the village settlements

\begin{tabular}{|c|c|}
\hline $\begin{array}{l}\text { Köy yerleşmelerinin mahalleye dönüșmmesini olumsuz karşlama sebepleriniz } \\
\text { nelerdir? }\end{array}$ & $(\%)$ \\
\hline $\begin{array}{l}\text { Köyde ev ve eklentileri gibi inşaat yapma işlerinin maliyetin çok artmasmdan } \\
\text { dolayı güçleşmesi }\end{array}$ & 60,1 \\
\hline Su faturalarmın çok yüksek tutarlarda gelmesi & 25 \\
\hline Gelen faturalara bağlı olarak köyde hayat pahalılığının artması & 1,6 \\
\hline Beldelerin ve köylerin tïzel kişiliğinin kalkmış olması & 1,4 \\
\hline $\begin{array}{l}\text { Büyükșehir belediyesinin MUBIS üzerinden hizmet verme konusunda sürekli } \\
\text { ilçe belediyesine yönlendirme yapması }\end{array}$ & 11,3 \\
\hline Belde ve köye ait taşmır-taşınmaz malları büyükşehire geçmiş olması & 0,6 \\
\hline Toplam & 100 \\
\hline
\end{tabular}

3.3.6. Katılımcıların 6360 sayılı yasanın getirdiği hak ve yükümlülükleri bilme durumları

Kanunun getirdiği hak ve yükümlülükler konusunda katılımclların \%89'u yükümlüklerinin yasa sonrası daha çok arttı̆ını belirtirken, \%10'u konuyla ilgili fikir sahibi olmadıklarını ifade etmişlerdir (Tablo 10).

Tablo 10. Kanunun getirdiği hak ve yükümlülükler hakkında düşünceler Table 10. Assessments on the rights and obligations of the Law

\begin{tabular}{|l|c|}
\hline Kanunun getirdiği hak ve yükümlülükler hakkında ne düşünüyorsunuz? & $(\%)$ \\
\hline Haklarım daha fazla & 1.0 \\
\hline Yükümlülüklerim daha fazla & 89 \\
\hline Fikrim yok & 10 \\
\hline Toplam & $\mathbf{1 0 0}$ \\
\hline
\end{tabular}

Yükümlülüklerinin arttı̆ını söyleyen ve büyük bir çoğunluğu tarım yapan, suyu ücretsiz kullanan, emlak vergisi vermeyen köylülerden oluşan katılımcılar büyükşehir belediye sınırlarına dâhil olmakla sahip oldukları bu hak ve muafiyetleri yitirdiklerinden dolayı yükümlülüklerinin daha çok arttğını belirtmişlerdir. Ayrıca, büyükşehir belediyesi olmanın sebep olduğu yasal sınırlamalardan dolayı köylünün önemli gelir kapısı olan hayvancılık faaliyetlerinin de her geçen gün azaldığını ifade etmiş- lerdir. Köyde yapılacak ev ve eklentileri gibi yapılarla ilgili harç ve vergi ödemelerininse bir diğer yükümlülük olduğunu beyan etmişlerdir.

Katılımcıların 6360 Sayılı Yasa'nın getirdiği hak ve yükümlülükler konusunda en çok şikâyetçi olanların eski belde belediyesi sakinlerinin olduğu görüldü. "Yükümlülüklerimiz çok artt, eskiden kışın kar yağdığı zaman yollarımız kapanınca belde belediyemizin iş makinaları aynı gün yolları açardı, şimdi bize ait hiçbir şey kalmadı. Mahalleye dönüşen eski belde belediyelerinin sahip olduğu tüm hakları ellerinden alındı (K3, 53 Yaş, Muhtar)”.

\subsubsection{Katılımcıların 6360 sayılı kanunun öncesi ve sonrası ara-} sında köylerinde alma bakımından değişiklikler olup-olmama durumuna yönelik görüşleri

Yasa sonrası köylerinde büyük değişiklikler olduğunu belirtenlerin oranı \% 66,3 iken herhangi bir değişiklik olmadığını ileri sürenlerin oranı \% 20,2, konu hakkında fikrim yok diyenlerin oranı ise \% 13,5'dir (Tablo 11). Değişiklik olduğuna yönelik görüş bildiren katılımcıların tamamına yakını özellikle kanalizasyon sistemi, çocuk oyun alanları, mezarlıkların bakımı, haftada 2-3 gün büyükşehir belediyesi tarafindan çöplerin toplanması, belediye otobüslerinin köye kadar gelmesi, tohumluk mahsullerin verilmesi ve belediyenin düzenlediği çiftçi eğitimlerini önemli değişiklikler arasında saymışlardır.

Tablo 11. Kanunun uygulanmasından öncesi ve sonrası arasında köylerin hizmet alma durumu.

Table 11. Status of receiving services of villages before and after the implementation of the law.

\begin{tabular}{|l|c|}
\hline $\begin{array}{l}\text { Kanunun uygulanmasndan öncesi ve sonrası arasında köyünüzde } \\
\text { hizmet alma bakımından bir değisiklik oldu mu? }\end{array}$ & $(\%)$ \\
\hline Evet & 66,3 \\
\hline Hayır & 20,2 \\
\hline Fikrim yok & 13,5 \\
\hline Toplam & $\mathbf{1 0 0}$ \\
\hline
\end{tabular}

Katılımcılar 6360 Sayılı Yasa sonrası çoğunlukla daha iyi hizmet aldıklarını belirtmişlerdir. "Eskiden köye ne belediye otobüsü gelirdi ne de çöp kamyonu gelirdi, şimdi haftanın üç günü çöpler toplanıyor ve belediye otobüsü geliyor, çok rahatladık (K4, 35 Yaş, Bayan, Ev Hanımı)." Köy mezarlıkları bile bakıma alındı (K5, 41 Yaş, Çiftçi)". Köy içi yollar tamamen parke taşla kaplandı, kanalizasyon yapıldı, çocuk parkları yapıldı eskiye göre köyümüz daha temiz ve düzenli bir yer oldu (K6, 37 Yaş, Imam)".

\subsubsection{0 sayılı kanun sonrası köylerinde en fazla değişikliğin olduğu hizmet alanı}

Köylerinde yasa sonrası büyük değişiklikler olduğunu belirten katılımcıların \% 77,6'sı özellikle alt yapı hizmetleri konusunda değişimler olduğunu belirtmişlerdir. Ayrıca ekonomik anlamda organik ve iyi tarım destekleri, bitkisel ve hayvansal üretimde kaliteyi arttırmak için projeler, küçük ölçekli tarım alet ve makinaları ile her türlü destek verildiğini belirten katılımcıların oranı ise \% 19,8'dir (Tablo 12). 
Tablo 12. Kanun sonrası köylerinde en fazla değişikliğin olduğu hizmet alanı Table 12. The service area with the most changes in villages after the law

\begin{tabular}{|l|c|}
\hline $\begin{array}{l}\text { Kanun sonrasında en fazla değişikliği hangi hizmet konusunda } \\
\text { hissettiniz? }\end{array}$ & $\mathbf{7 \%}$ \\
\hline Alt yapı hizmetleri & 19,8 \\
\hline Ekonomik destekler & 1,1 \\
\hline İstihdam & 1,5 \\
\hline Genel hizmet alımı & $\mathbf{1 0 0}$ \\
\hline Toplam & \\
\hline
\end{tabular}

3.3.9. Katılımcıların 6360 sayılı yasa sonrası köy tüzel kişiliğine ait taşınır ve taşınmaz malların belediye mülkiyetine geçmesi ile ilgili düşünceleri

Anket çalışmasının yapıldığı mahallelerde yaşayanların \% 89’u köy tüzel kişiliğine ait taşınır ve taşınmaz malların belediye mülkiyetine geçmesini olumsuz olarak değerlendirirken, sadece \%11'lik bir oranda katlımcı olumlu görüş bildirmiştir (Tablo 13). Tüzel kişiliği kaldırılan belde belediyelerinde ikamet edenlerin tamamı bu durumun olumsuz olduğunu, yasa öncesi kış aylarında kapanan köy yollarını kendi belediyelerine ait iş makineleri ile kısa bir sürede açarken şimdi ilçe belediyesini beklediklerini ve belediyenin bu konularda çok yetersiz kaldığını belirtmişlerdir.

Tablo 13. 6360 Sayılı yasa öncesi köy tüzel kişiliğine ait taşınır ve taşınmaz malların belediye mülkiyetine geçmesi ile ilgili katılımcıların düşünceleri

Table 13. The opinions of the participants regarding the transfer of movable and immovable property belonging to the village legal entity before the Law No. 6360 to the ownership of the Municipality

\begin{tabular}{|l|c|}
\hline $\begin{array}{l}\text { Köy tüzel kişiliğine ait taşınır ve taşınmaz malların Belediye } \\
\text { mülkiyetine geçmesi hakkında ne düşünüyorsunuz ? }\end{array}$ & (\%) \\
\hline Olumlu & 11 \\
\hline Olumsuz & 89 \\
\hline Toplam & $\mathbf{1 0 0}$ \\
\hline
\end{tabular}

\subsubsection{Katılımcıların 6360 sayılı kanun sonrası büyükşehir ve} ilçe belediyesinden beklentileri

Katılımcılara yasa kapsamında belediyelerden beklentileri sorulmuş; köy içi ve çevre yolların yapılması $(\% 17,4)$, bozuk kanalizasyon şebekelerinin onarılması $(\% 13,4)$, ulaşım konusunda mahallelere belediyenin daha sık sefer düzenlenmesi $(\% 26,8)$, sosyal tesis yapılması $(\% 14,6)$, içme suyu sorununun giderilmesi (\%2,4 ) gibi hizmetlerin öncelikli beklentiler olduğu tespit edilmiştir (Tablo 14).

Tablo 14. Kanun Sonrası Büyükşehir ve ilçe belediyesinden beklentiler Table 14. The expectations from metropolitan and district municipalities after the law

\begin{tabular}{|l|c|}
\hline Kanun sonrası büyükşehirve ilçe belediyesinden beklentileriniznelerdir? & $(\%)$ \\
\hline Köy içi ve çevre yolların yapımına devam edilmesi & 17,4 \\
\hline Sosyal tesislerin yapılması & 14.6 \\
\hline Relediye otohïslerinin daha sık sefer dïzenlemesi & 26.8 \\
\hline Kanalizasyon şebekelerinin onarılması & 13.4 \\
\hline Mczarlıkların bakımına ve çöplcrin toplanmasına dcvam cdilmosi & 21.4 \\
\hline İçme ve kullanma suyu sorununun giderilmesi & 2,4 \\
\hline Çocuk oyun alanı ve halı saha yapılması & 4 \\
\hline Toplam & $\mathbf{1 0 0}$ \\
\hline
\end{tabular}

3.3.11.Katılımcıların 6360 sayılı kanun sonrası herhangi bir inşaat işinde belediyeden imar izni alınıp-alınmayacağına yönelik bilgi düzeyleri

Yasa sonrası herhangi bir inşaat işinde belediyeden izin alınacağını bilen katılımcıların oranı \% 85,2 iken, bilmeyenlerin sayısı ise \%14,8'dir (Tablo 15). Katılımcılar şikâyet olmadığı sürece izinsiz olarak imar işlerini yapmaya çalıştkklarını, diğer türlü imar izni ile ilgili masrafların çok olmasından dolayı ekonomik anlamda zorluk çektiklerini belirtmişlerdir.

Tablo 15. 6360 Sayılı Kanun sonrası herhangi bir inşaat işinde belediyeden imar izni alınıp-alınmayacağına yönelik bilgi düzeyleri

Table 15. Levels of knowledge on whether a construction permit can be obtained from the municipality in any construction work after the Law no. 6360

\begin{tabular}{|l|c|}
\hline $\begin{array}{l}\text { Herhangi bir inşaat işinde belediyeden imar izni alınacağmı biliyor } \\
\text { musunuz? }\end{array}$ & $(\mathbf{\%})$ \\
\hline Biliyorum & 85,2 \\
\hline Bilmiyorum & 14,8 \\
\hline Toplam & $\mathbf{1 0 0}$ \\
\hline
\end{tabular}

\subsubsection{Katılımcıların 6360 sayılı kanun sonrası tarım arazileri-} nin imara açılması ile ilgili düşünceleri

Katılımcıların \% 64,4'ü yasaya bağlı olarak tarım arazilerinin imara açılmasını olumlu karşılarken, \% 35,6'sı ise olumsuz karşılamaktadır (Tablo 16). Olumlu karşılayan katılımcılarının en önemli gerekçeleri tarım arazilerinin değer kazanacağı düşüncesinden kaynaklanmaktadır. Olumsuz karşılayan katılımcılar ise, gelecek yıllarda tarım arazilerin imara açılmasının köy yerleşim yerlerinde tarım ve hayvancılık faaliyetlerinin ciddi ölçüde azalmasına yol açabileceğini belirtmişlerdir.

Katılımcılar her ne kadar tarımsal arazilerinin imara açılması konusunda belediye meclis kararı gerekse bile, konut alanları, ticaret ve sanayi alanları gibi amaçlarla tarımsal arazilerin imara açılma riskinin bulunduğunu belirtmişlerdir. Sarayönü-Kurşunlu mahallesi girişinde TOKi tarafindan 79 konutluk ihalenin yapılarak, konutların yapımına başlanmasını örnek olarak göstermişlerdir (Şekil 6).

Tablo 16. Tarım arazilerinin imara açılması ile ilgili düşünceler Table 16. Opinions about the opening of agricultural land to the settlement

\begin{tabular}{|l|c|}
\hline Tarım arazilerinin imara açılması ile ilgili ne düşünüyorsunuz? & $(\%)$ \\
\hline Olumlu & 64.4 \\
\hline Olumsuz & 35,6 \\
\hline Toplam & $\mathbf{1 0 0 . 0}$ \\
\hline
\end{tabular}

Kathlımcıların bir kısmı tarım arazilerinin değerleneceğini düşünürken bir kısmı ise verimli tarım arazilerinin imara açılmaması gerektiğini belirtmişlerdir. "Bakın köyümüzün girişindeki tarlalarımıza TOKi konut yapıyor, hiç tanımadığımız insanlar gelip köyümüzden arazi alıp, ev yaptırarak yerleşmeye başladı (K7, 40 Yaş, Çiftçi). "Ana yol kenarlarında tarım arazileri üzerine tavuk çiftlikleri yapıldı, yazın bu çiftliklerden etrafa yayılan kokulardan evimizde oturamaz hale geldik (K9, 32 Yaş, Ev Hanımı)". 


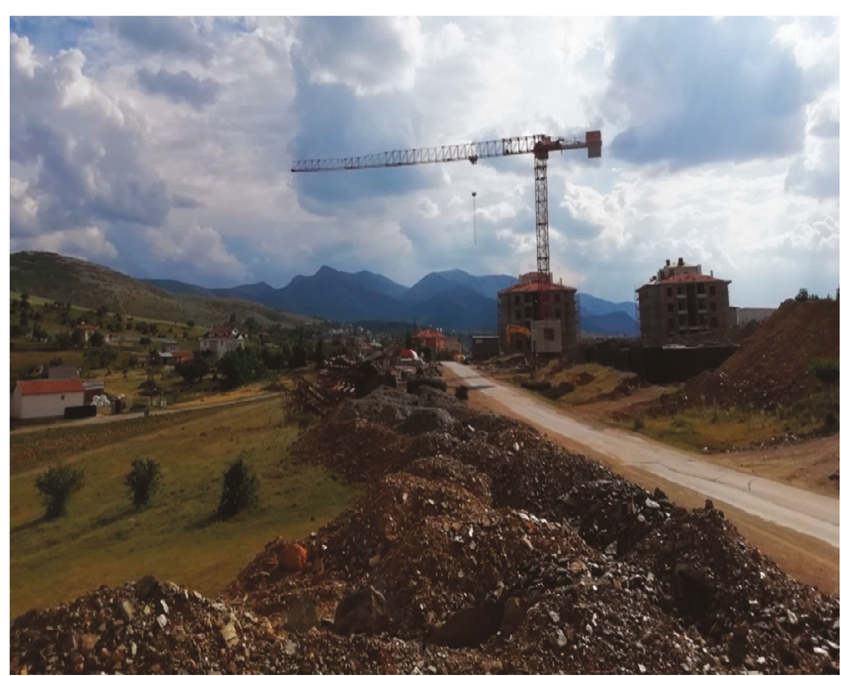

Şekil 6. 6360 Sayılı yasayla tarım arazilerinin imara açılması sonucu yapımına başlanan Sarayönü Kurşunlu mahallesi 79 konutluk TOKi inşaat alanı

Figure 6. Sarayönü Kurşunlu neighborhood, whose construction started as a result of the zoning of agricultural lands with the Law No. 6360, has a TOKI construction area of 79 houses.

\section{Sonuç}

2012 yılında 6360 Sayılı Yasa'nın çıkarılmasından bu yana yedi yıl geçmesine rağmen yasaya yönelik tartışmalar halen devam etmektedir. Tartışma konularının başında ise kırsal yerleşim birimleri gelmektedir. Yasanın yürürlüğe girdiği ilk yıl büyükşehir belediyelerinin sunacağı hizmetler açısından şehir merkezinde yer alan şehirsel mahalleler ile kırsalda yer alan merkeze uzak kırsal mahalleler arasında büyük farklılıkların olacağı düşünülmüştür. Özellikle Türkiye'nin coğrafi yapısına baktığımız zaman kırsal ve şehirsel yerleşim birimleri arasındaki mekânsal uzaklık çok fazladır. Bu durum büyükşehir belediyelerince sunulacak hizmetlerin kırsal yerleşim birimlerine ulaştrılması konusunda ciddi kaygılar oluşturmuştur. Özellikle kırsal mahallelerdeki alt yapı hizmetlerinin belediyelerce yapılacak olması, il özel idarelerinin kapatılması ve buna bağlı olarak köy bütçelerinin kaldırılması, geçmişte köy-devlet işbirliğiyle yapılan (alt yapı hizmetleri, yol yapımı, okul, sağlık ocağı, içme suyu şebekeleri gibi) çalışmaların yapılamayacağı endişesini doğurmuştur. Buna gerekçe olarak birçok büyükşehir belediyesinin mali gücünün zayıf olması gösterilmiştir. Şehir merkezinde yer alan mahallelere dâhi yeterli hizmet götürülemezken kilometrelerce uzaklıkta bulunan kırsal mahallelere hangi mali destekle, nasıl ve ne zaman hizmet götürüleceği merak konusu olmuştur. Ayrıca imar işleri ile ilgili izin alma ve vergi ödemeleri, su faturası, eskiden köy tüzel kişiliğine ait menkul ve gayrimenkullerin büyükşehir belediyelerine devredilmesi, tarım arazilerinin imara açılma riski, ahırların köy yerleşim alanlarının dışına çıkartılması ve buna bağlı olarak hayvancılık faaliyetlerinin bu durumdan zarar göreceği endişesi, yasanın kırsal mahalleler ile ilgili tartışma konularının odak noktasını oluşturmuştur.

Mevcut endişeler ışığında Türkiye'nin en geniş yüzölçümüne ve yoğun kırsal nüfusa sahip ili Konya'ya bağlı dört ilçenin toplam 20 kırsal mahallesinde yapılan anket sonucunda 6360 Sayılı Kanunun kırsal yerleşim birimlerinde sahadaki karşılığı ölçülmüştür. Sahada dört ilçenin seçilmesinde özellikle il genelinde çıkacak sonuçları vermesi açısından en uzak ve en yakın mesafede ikişer ilçe tercih edilmiştir. Bu sayede yasanın uygulanmaya başladığı tarihten bugüne kadar olan süreçteki tecrübelerden elde edilen verilerin genel bir değerlendirmesi yapılarak gelecek için öngörülerde bulunmak mümkün olmuştur.

Konya il genelinde anket uygulanan katılımcıların büyük bir kısmı köylerinin mahalleye dönüşmesinden memnun olduklarını belirtmişlerdir. Bu durumun en önemli sebebini ise yasa öncesi görmedikleri hizmeti ve ilgiyi yasa sonrasında görmelerine bağlamışlardır. Konuyla ilgili memnuniyetsizliklerini dile getirenlerin ise genelde eski belde belediyesi statüsünde yaşayan mahalle sakinlerinden oluştuğu görülmüştür. 6360 Sayılı Yasa sonrası katılımcıların Türkiye'nin en geniş yüzölçümüne sahip ilinde merkeze çok uzak mesafelerde olmalarına rağmen memnun olmalarının özellikle Konya ilinin model olabilecek uygulamalarıyla bağlantılı olduğu görülmektedir. Özellikle MUBiS ve il genelinde kurulan yedi hizmet bölgesi, kırsal mahallelerdeki sorunlara büyükşehir belediyesinin hızlı ve etkili bir şekilde hizmet sunmasını sağlamaktadır. Ayrıca Tarımsal Hizmetler ve Koordinasyon Dairesi Başkanlığı tarafindan; kırsal mahallelerde bulunan çiftçilere eğitimler verilmesi, toprak etüdü, toprak ve su analizleri, organik tarım ve iyi tarım destekleri, bitkisel ve hayvansal üretimde kaliteyi arttırmak için projeler, küçük ölçekli tarım alet ve makinaları ile her türlü tarımsal desteğin sağlanması anket uygulanan kırsal mahallelerin tamamında önemli hizmetler olarak değerlendirilmiştir. Yine alt yapı hizmetleri, ulaşım, çöplerin toplanması, mezarlıkların bakımı, mahalle içi yolların büyük bir bölümüne kilit taş döşenmesi ya da asfaltlanması, çocuk parkları ve spor alanlarının yapılması daha önce kırsal mahalle sakinlerinin görmediği hizmetler arasında sayılmıştir.

Konya özelinde genel bir değerlendirme yaptı̆̆ımızda yasa sonrası kırsal yerleşim birimlerinde yapılan hizmetlerin Türkiye'ye model olabilecek düzeyde uygulamalar olduğu görülmüştür. Ancak kırsal yerleşimler, kırsal nüfus ve kırsal kalkınma konusu sadece büyükşehir belediyelerinin hizmet anlayışına indirgenecek bir konu değildir. Her ne kadar idari ve hukuki anlamda köyler şehirsel yaşama uygun mahallelere dönüştürülmek istense de bu mahallelerin gerçek sakinleri sonuçta köylülerdir. Adı ne olursa olsun kırsal mahallelerin yerleşik halkı tarım ve hayvancılık faaliyetlerine devam edecek ve eski köy yaşamını sürdürecektir. 6360 Sayılı Yasa'nın da Türkiye genelinde mevcut bu yaşamın sürdürülebilirliğini sağlayan, kırsal yaşam kültürünü ve doğal ortamını koruyan, planlı ve yerinde uygulamalar getiren düzenlemelere intiyacı bulunmaktadır.

\section{Kaynakça}

6360 Sayılı On Dört Illde Büyükşehir Belediyesi ve Yirmi Yedi İlçe Kurulması ile Bazı Kanun ve Kanun Hükmünde Kararnamelerde Değişiklik Yapılmasına Dair Kanun. Resmi Gazete, 28489 $12 / 11 / 2012$.

Adıgüzel, Ş. (2012). 6360 Sayılı Yasa'nın Türkiye'nin Yerel Yönetim Dizgesi Üzerine Etkileri: Eleştirel Bir Değerlendirme, Toplum ve Demokrasi Dergisi, 14: 153-176.

Ayyıldız, M., Çiçek, A., Ayyıldız, B. (2016). 6360 Sayılı Büyükşehir Yasasının Kırsal Kesime Olası Etkileri. Nevşehir Bilim ve Teknoloji Dergisi TARGID, Özel Sayı: 280-285.

Bekdemir, Ü., Kocaman, S., Polat, S. (2014). Yeni Büyükşehir Yasası Sonrasında Türkiye'de Şehir Nüfusu Ve Şehir Yerleşmeleri, Doğu Coğrafya Dergisi, 32: 277-297.

Bulut, Y., Dönmez, D. (2019). 6360 Sayılı Düzenlemeyle Oluşan Büyük 
şehir Modelinde Büyükşehir Belediyesi İle illçe Belediyeleri Arasında Yaşanan Sorunlar ve Çözüm Önerileri: Hatay ili Örneği. Uluslararası Yönetim Akademisi Dergisi, 2 (1) , 29-40.

Çukurçayır, M. A., Negiz, N., Yemen, A. (2014). 6360 Sayılı Kanun'un Uygulamasında Köy(lü) mü Mahalle(li) mi?: Katıl(a)mayanlar AçIsından Bir Değerlendirme, Uluslararası XI. Kamu Yönetimi Forumu Bildiriler Kitabı: AfroAvrasya Coğrafyasında Kamu Yönetimi Uygulamaları ve Sorunları. Ankara: TODAiE Yayınları, Ankara.

Ekonomi Raporu (2018). Konya: Ticaret Odası Yayınları, Konya.

Eryılmaz, B. (2006). Tanzimat ve Yönetimde Modernleşme. İstanbul: İşaret Yayınları, ìstanbul.

Göküş, M., Alptürker, H. (2016). 6360 Sayılı Yasa Ille Köy Yönetiminden Mahalle Yönetimine Geçiş Sonrası Etkin Hizmet Sunumuna Iliş̧in Muhtarların Görüşü: Silifke Köyleri Örneği. Selçuk Üniversitesi Sosyal ve Teknik Araştırmalar Dergisi 11: 67-86.

Gürbüz, M., Yıldırım, U., Belli, A. (2014). Büyükşehir Belediye Kanunu'nun Kahramanmaraş İli Ölçeğinde Analizi. Adnan Menderes Üniversitesi Sosyal Bilimler Enstitüsü Dergisi 1: 102-135.

Kalpaklığlu, G. (2017). 6360 Sayılı Büyükşehir Yasasının Kırsal Kesime Etkilerinin Değerlendirilmesi (Ordu Büyükşehir Belediyesi Örneği ). Gaziosmanpaşa Üniversitesi Fen Bilimleri Enstitüsü Tarım Ekonomisi Anabilim Dalı, Yayınlanmamış Yüksek Lisans Tezi, Tokat.

Keleş, R. (2013). Kentleşme Politikası, Ankara: Imge Kitabevi, Ankara.

Keleş, R. (1985). Türkiye'de Anakent Yönetimi, Amme Idaresi Dergisi, 2: 69-82.

Kırmızı, M. (2019). 6360 Sayılı Yasanın Kent ve Kır Alanlarına Etkileri: Diyarbakır Örneği. Manisa Celal Bayar Üniversitesi Sosyal Bilimler Enstitüsü Kamu Yönetimi Anabilim Dalı, Yayınlanmamış Yüksek Lisans Tezi, Manisa.

Kut Görgün, E., Yörür, N. (2017). 6360 Sayılı Büyükşehir Kanunu Sonrası Kırsal Alanları Yeniden Düşünmek- İzmir Örneği. Aydın iktisat Fakültesi Dergisi 2: 11-27

Oktay, T. (2009). Belediyenin Tarihsel Gelişimi (Ed: Bozlağan, R. ve Demirkaya Y. Türkiye'de Yerel Yönetimler içinde). Ankara: Nobel Yayınları, Ankara.

Ortaylı, i. (2000). Tanzimat Devrinde Osmanlı Mahalli Idareleri 18401880, Ankara: Türk Tarih Kurumu Yayınları, Ankara.

Özçağlar, A. (2015). Yönetsel Coğrafya. Ankara: Nika Yayınevi, Ankara.

Özçağlar, A. (2016). Büyükşehir Belediyeli illerde Kır ve Kent Nüfusunun Tespiti Mümkün mü?. TÜCAUM Uluslararası Coğrafya Sempozyumu 2016, Bildiriler Kitabı Tam Metin: 271-291, Ankara

Öztürk, Y. (2014). Kuruluşundan 1950'ye Kadar Bursa Belediyesi ve Hizmetleri. Atatürk Üniversitesi Sosyal Bilimler Enstitüsü Tarih Anabilim Dalı, Yayınlanmamış Doktora Tezi, Erzurum.

Söylemez, A., Tekin, Ö. F. (2016). Türkiye'de Büyükşehir Yönetimi ve 6360 Sayılı Yasanın Getirdiği Değişim: Konya Örneği, Kamu Yönetiminde Değişimin Yönü ve Etkileri (KAYFOR 13 Bildiri Kitabı). Konya:1435-1449.

Susta Olgun G., Gülçubuk B. (2016). Kırsalın Dönüşümünde Fırsat ve Tehditleriyle Yeni Büyükşehir Yasası'nın Analizi. XII. Ulusal Tarım Kongresi 2016: 1059-1068.

Susta Olgun G. (2018). 6360 Sayılı Yasa Ille Oluşan Yeni Büyükşehir Yasası́nın Kırsal Alanda Hizmet Etkililiği Açısından İncelenmesi: İzmir ili Kiraz Illçesi Araştrrması. Ankara Üniversitesi Fen Bilimleri Enstitüsü Tarım Ekonomisi Anabilim Dalı, Ankara.

Şenol, E. (2019). Büyükşehir Statüsündeki İllerde Kırsal Nüfusun Tespiti: Ordu ili Örneği. Türk Coğrafya Dergisi 72: 53-63.

Taş, B. (2017). Türkiye'de Yönetim ve Yerleşme Açısından Mahalleler, TCK 75. Kuruluş Yılı Uluslararası Kongresi, Bildiriler Kitabı Tam Metin: 25-30, Ankara.

Tolun Denker, B. (1977). Yerleşme Coğrafyası-Kır Yerleşmeleri. İstanbul: İstanbul Üniversitesi Yayınları, İstanbul.

Usta, S., Akman E., Kocaoğlu, M. (2018). 6360 Sayılı Kanun'un Büyükşehir Belediye Sistemine Etkileri: Konya Büyükşehir Belediyesi Örneği. TESAM Akademi Dergisi, Yerel Yönetimler Özel SayıSI,217-249.

Yılmaz, M. (2015). Türkiye'de Kırsal Nüfusun Değişimi ve Illlere Göre Dağılımı (1980-2012). Doğu Coğrafya Dergisi, 33: 161-188.
Yörükoğlu, F. (2009). Türk Belediyeciliğinin Gelişim Süreci, Mevzuat Dergisi, 135.

Zengin, O.(2014). Büyükşehir Belediyesi Sisteminin Dönüşümü: Son On Yılın Değerlendirmesi. Ankara Barosu Dergisi, 2014/2: 91-116.

\section{Internet Kaynakları}

https://biruni.tuik.gov.tr/medas/?kn=95\&locale=tr (Son Erişim: 17.06.2019).

http://konya.com.tr/tarihce/ (Son Erişim:06.05.2019).

http://www.tuik.gov.tr/PreTablo.do?alt_id=1047 (Son Erişim: 09.03.2020). 